\title{
Synthesis and Evaluation of Pyrimidine Steroids as Antiproliferative Agents
}

\author{
Alejandra Cortés-Percino ${ }^{1}$, José Luis Vega-Báez ${ }^{1}$, Anabel Romero-López ${ }^{2}$, Adrián Puerta ${ }^{3}$, \\ Penélope Merino-Montiel ${ }^{1}{ }^{\mathbb{D}}$, Socorro Meza-Reyes ${ }^{1}$, José M. Padrón ${ }^{3, *}$ a and \\ Sara Montiel-Smith ${ }^{1, *}$ \\ 1 Facultad de Ciencias Químicas, Benemérita Universidad Autónoma de Puebla, Ciudad Universitaria, \\ 72570 Puebla, Pue., Mexico; ale891930@hotmail.com (A.C.-P.); jose.vega@correo.buap.mx (J.L.V.-B.); \\ penelope.merino@correo.buap.mx (P.M.-M.); maria.meza@correo.buap.mx (S.M.-R.) \\ 2 Instituto de Física “Luis Rivera Terrazas” Benemérita Universidad Autónoma de Puebla Ecocampus \\ Valsequillo, 72960 San Pedro Zacachimalpa, Pue., Mexico; anabelrl@ifuap.buap.mx \\ 3 BioLab, Instituto Universitario de Bio-Orgánica “Antonio González" (IUBO-AG), Centro de Investigaciones \\ Biomédicas de Canarias (CIBICAN), Universidad de La Laguna, c/ Astrofísico Francisco Sánchez 2, \\ 38206 La Laguna, Spain; apuertaarocha@gmail.com \\ * Correspondence: jmpadron@ull.es (J.M.P.); maria.montiel@correo.buap.mx (S.M.-S.); \\ Tel.: +34-922-316-502 (ext. 6126) (J.M.P.); +52-222-2295500 (ext. 7382) (S.M.-S.)
}

Received: 4 September 2019; Accepted: 11 October 2019; Published: 12 October 2019

\begin{abstract}
A small and focused library of steroidal non-fused and fused pyrimidines was prepared from pregnenolone acetate and diosgenin, respectively. The key step was the cycloaddition reaction of nitrogen-containing 1,3-binucleophiles with the steroidal $\alpha, \beta$-unsaturated ketone. Urea, thiourea and guanidine reacted in a similar manner and afforded the steroidal pyrimidines in good yields. The antiproliferative tests against human tumor cell lines gave $\mathrm{GI}_{50}$ values in the micromolar range and had no effect on healthy fibroblasts. Additional experiments indicated that the compounds did not act as P-glycoprotein substrates, thus avoiding the rise of drug resistance. The fused steroidal pyrimidinethione was selected as drug lead for further testing due to its strong antiproliferative activities within the low micromolar range.
\end{abstract}

Keywords: steroids; pyrimidine; heterocycle; cycloaddition reactions; antiproliferative activity

\section{Introduction}

The direct use of natural products as drugs is limited because their physicochemical properties are often far from ideal. However, they represent an excellent starting point in drug discovery programs. In fact, $50 \%$ of approved drugs have a natural origin and many synthetic compounds were disclosed as using natural products [1-3]. In the particular case of cancer, the amount of natural product-based drugs rises up to $55 \%$.

When considering the chemical structure of small-molecule approved drugs, $59 \%$ of them contain a nitrogen heterocycle [4]. From this subset, six-membered rings (59\%) are the most common, followed by five-membered $(39 \%)$ and fused rings (14\%). In particular, pyrimidine approved drugs are used for the treatment of three main disease classes: anti-infective, cardiovascular, and oncological. It has been reported that the conjugation of a pyrimidine moiety with a steroidal framework resulted in a synergistic effect of both biologically active molecular scaffolds providing new compounds with antiproliferative [5-9] (Figure 1), antioxidant [10], anti-Alzheimer [11], or antibacterial properties [12].

Based on the beneficial importance of these hybrid scaffolds, we moved our attention to the synthesis of steroidal pyrimidines in order to look for new antiproliferative compounds. We have previously reported some monomeric and dimeric steroidal triazolopyrimidine derivatives [13] and a 
family of steroidal spiro heterocycles from trans-androsterone and estrone bearing oxazolidin-2-one and 2-aminooxazoline motifs at C-17 [14]. A remarkable antiproliferative activity was found for some of the estrone derivatives with $\mathrm{GI}_{50}$ values at the low micromolar level.<smiles>[X]=C(Cl)OC(C)=O</smiles><smiles>CC(C)CCC[C@H](C)[C@H]1CCC2C3c4c(-c5ccccc5)nc(O)nc4C4C[C@@H](Cl)CC[C@]4(C)C3CC[C@]21C</smiles><smiles>[R]C1=CSC2=NC(c3ccccc3)C3=C(CC4C5CCc6cc(O)ccc6C5CC[C@@]34C)N12</smiles>

<smiles>COC(c1ccccc1)c1ccccc1</smiles>

Figure 1. Illustrative biologically active steroidal pyrimidines.

Herein, we report the synthesis of six new pregnenolone and diosgenine-based pyrimidines attached or fused at C-17 and their evaluation as antiproliferative agents.

\section{Results and Discussion}

\subsection{Chemistry}

This pyrimidine formation includes 1,4-addition of 1,3-binucleophilic agents to an enone and the subsequent intramolecular addition of an $\mathrm{NH}_{2}$ group to ketone followed by elimination of $\mathrm{H}_{2} \mathrm{O}$.

We selected guanidine, urea, and thiourea as 1,3-binucleophilic agents and two related pregnenolone frameworks in order to prepare two series of steroidal pyrimidines, namely non-fused and fused pyrimidine steroids. The synthetic pathway is outlined in Scheme 1. The synthesis of the non-fused pyrimidine steroids $(3 \mathbf{a}-\mathbf{c})$ was started from commercially available pregnenolone acetate (1). The acetate group was hydrolyzed under standard basic conditions and in situ the ketone was converted into the desired $\alpha, \beta$-unsaturated ketone 2 through a Claisen-Schmidt condensation with benzaldehyde under basic conditions [15].

Finally, the cycloaddition reaction of 2 with guanidine, urea, or thiourea, respectively, was carried out. For the basic catalysis ethanolic solutions of $\mathrm{KOH}$ at diverse concentrations were essayed; however, the reaction did not take place.

Subsequently, changing the basic conditions to $t$ - $\mathrm{BuONa} / \mathrm{BuOH}$ afforded the non-fused pyrimidine steroids $3 \mathbf{a}-\mathbf{c}$ in $56-68 \%$ yield. Otherwise, for the synthesis of fused pyrimidine steroids $7 \mathbf{a}-\mathbf{c}$, commercially available diosgenin 4 was transformed into the pseudosapogenin 5 through a selective $F$ ring cleavage [16]. Then, the oxidative rupture of the intermediate 5 afforded the $\alpha, \beta$-unsaturated ketone 6 . Finally, refluxing ketone 6 with guanidine, urea, or thiourea, respectively, in alcoholic solution of potassium hydroxide led to the fused pyrimidine steroids $7 \mathbf{a}-\mathbf{c}$ in $52-65 \%$ yield. Table 1 summarizes the results of the cycloaddition reaction of $\alpha, \beta$-unsaturated ketones 2 and $\mathbf{6}$. Reaction times were in the range $7-14 \mathrm{~h}$, while yields were modest and ranging from $52 \%$ to $68 \%$. These results pointed out that the reactivity of the 1,3-binucleophile was not affected by the electronegativity of the exocyclic heteroatom. 

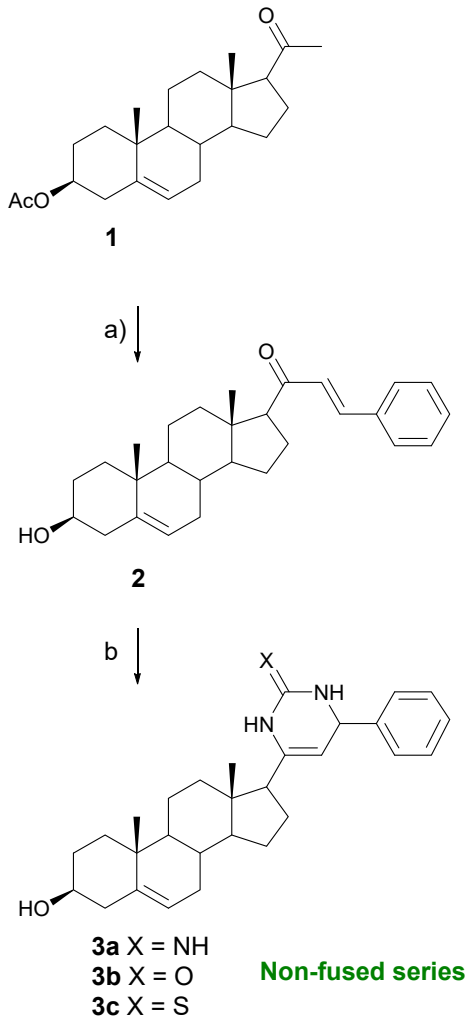

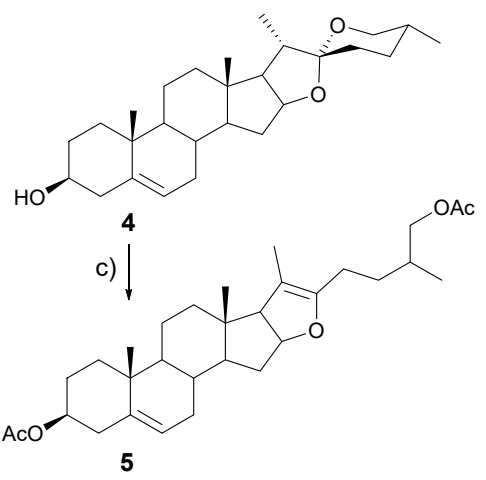<smiles>CC(=O)C1=CCC2C3CC=C4C[C@@H](O)CC[C@]4(C)C3CC[C@]12C</smiles>

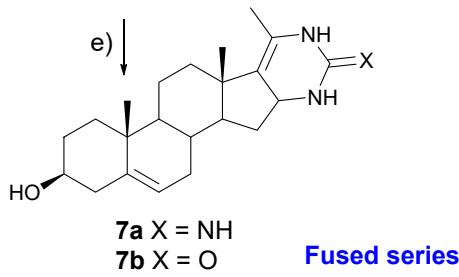

$7 c X=S$

Scheme 1. Reagent and conditions (a) PhCHO, $\mathrm{KOH}, \mathrm{EtOH}, \mathrm{rt}, 98 \%$; (b) $t$-BuOK (THF $1 \mathrm{M}$ solution), $\mathrm{BuOH}$, guanidine, urea, or thiourea, 56-68\%; (c) $\mathrm{BF}_{3} \cdot \mathrm{Et}_{2} \mathrm{O}$, ATFAA, $\mathrm{CH}_{2} \mathrm{Cl}_{2}, \mathrm{rt}, 93 \%$; (d) $\mathrm{CrO}_{3}, \mathrm{AcOH}$, $\mathrm{DCM}, \mathrm{H}_{2} \mathrm{O}, 0{ }^{\circ} \mathrm{C}$ to $\mathrm{rt}, 82 \%$; and (e) $\mathrm{KOH}, \mathrm{EtOH}$, guanidine, urea, or thiourea, reflux, $52-65 \%$.

Table 1. Outcome of the cycloaddition reaction of ketones 2 and $\mathbf{6}$.

\begin{tabular}{ccccc}
\hline Series & Compound & $\mathbf{X}$ & Time (h) & Yield (\%) \\
\hline \multirow{3}{*}{ Non-fused } & 3a & N & 7 & 68 \\
& 3b & O & 12 & 56 \\
& 3c & S & 10 & 62 \\
\hline \multirow{3}{*}{ Fused } & 7a & N & 9 & 58 \\
& $7 \mathbf{b}$ & O & 14 & 52 \\
& 7c & S & 8 & 65 \\
\hline
\end{tabular}

\subsection{Antiproliferative Activity}

We studied the antiproliferative activity of $\alpha, \beta$-unsaturated ketones ( 2 and 6 ) and steroidal pyrimidines ( 3 and 7) against human cell lines following the guidelines of the National Cancer Institute [17]. For the tests we selected five human solid tumor cell lines from diverse origins and one human fibroblast cell line as a model of non-tumor cells. These cell lines were chosen as representative of drug sensitive (A549, HBL-100, and HeLa) and drug resistant (T-47D and WiDr) monolayer cultures based on previous studies. The steroidal anticancer drugs abiraterone and galeterone were also tested for comparison purposes. Table 2 shows the results expressed as $50 \%$ growth inhibition $\left(\mathrm{GI}_{50}\right)$. Compound $7 \mathbf{a}$ was not tested due to poor solubility under protocol conditions. Overall, all tested compounds $(\mathbf{2}, \mathbf{3 a}-\mathbf{c}, \mathbf{6}$, and $\mathbf{7 b}-\mathbf{c}$, compound $\mathbf{7 a}$ was not tested due to poor solubility under protocol conditions) showed antiproliferative activity against all the tumor cell lines. They also displayed a good selectivity towards the human fibroblast cells (healthy cells). The potency of the compounds is comparable to that of abiraterone and galeterone, with $\mathrm{GI}_{50}$ values in the $\mu \mathrm{M}$ range. The most potent compound of the series is $7 \mathbf{c}$, a fused steroidal pyrimidinethione, which showed $\mathrm{GI}_{50}$ values in the range 2.6-3.7 $\mu \mathrm{M}$ against all tumor cells and is harmless for fibroblasts $\left(\mathrm{GI}_{50}>100 \mu \mathrm{M}\right)$. This is a 
relevant finding, since our compounds are non-toxic to healthy cells, whilst the steroidal anticancer drugs inhibit the growth of fibroblasts at $\mathrm{GI}_{50}$ values as low as $4.5-5 \mu \mathrm{M}$.

Table 2. Antiproliferative activity $\left(\mathrm{GI}_{50}\right)$ against human solid tumor cells and human fibroblasts. ${ }^{\mathrm{a}}$

\begin{tabular}{ccccccc}
\hline \multirow{7}{*}{ Compound } & \multicolumn{7}{c}{$\begin{array}{c}\text { Cell Line } \\
\text { (Origin) }\end{array}$} \\
\cline { 2 - 7 } & $\begin{array}{c}\text { A549 } \\
\text { (Lung) }\end{array}$ & $\begin{array}{c}\text { HBL-100 } \\
\text { (Breast) }\end{array}$ & $\begin{array}{c}\text { HeLa } \\
\text { (Cervix) }\end{array}$ & $\begin{array}{c}\text { T-47D } \\
\text { (Breast) }\end{array}$ & $\begin{array}{c}\text { WiDr } \\
\text { (Colon) }\end{array}$ & $\begin{array}{c}\text { BJ-hTERT } \\
\text { (Fibroblasts) }\end{array}$ \\
\hline $\mathbf{2}$ & $23 \pm 1.6$ & $19 \pm 3.7$ & $3.3 \pm 0.3$ & $9.9 \pm 3.5$ & $6.3 \pm 0.5$ & $>100$ \\
3a & $4.4 \pm 1.0$ & $23 \pm 2.8$ & $6.1 \pm 1.2$ & $8.8 \pm 2.2$ & $8.3 \pm 1.1$ & $>100$ \\
3b & $11 \pm 2.9$ & $16 \pm 1.3$ & $14 \pm 3.6$ & $15 \pm 1.3$ & $15 \pm 3.5$ & $97 \pm 5.9$ \\
3c & $7.7 \pm 1.0$ & $45 \pm 7.9$ & $11 \pm 1.5$ & $13 \pm 2.3$ & $9.2 \pm 1.6$ & $>100$ \\
$\mathbf{6}$ & $26 \pm 5.2$ & $64 \pm 1.6$ & $3.6 \pm 0.4$ & $29 \pm 4.5$ & $37 \pm 2.1$ & $>100$ \\
$7 \mathbf{7 b}$ & $13 \pm 3.7$ & $15 \pm 3.2$ & $3.4 \pm 0.2$ & $15 \pm 1.9$ & $18 \pm 1.8$ & $>100$ \\
$7 \mathbf{7}$ & $3.4 \pm 0.5$ & $3.7 \pm 1.0$ & $2.6 \pm 0.7$ & $3.0 \pm 0.5$ & $3.1 \pm 0.4$ & $>100$ \\
Abiraterone & $95 \pm 0.8$ & $>100$ & $7.9 \pm 0.5$ & $24 \pm 4.5$ & $42 \pm 7.7$ & $4.5 \pm 1.0$ \\
Galeterone & $3.9 \pm 1.3$ & $10 \pm 0.9$ & $5.3 \pm 0.4$ & $2.1 \pm 0.1$ & $2.7 \pm 0.2$ & $5.0 \pm 1.3$ \\
\hline
\end{tabular}

${ }^{a} \mathrm{GI}_{50}$ values are given in $\mu \mathrm{M}$. Standard deviation was calculated from at least two independent experiments. Abiraterone and galeterone were used as reference drugs. Values in bold face represent the best antiproliferative data against tumor cell lines $\left(\mathrm{GI}_{50}<10 \mu \mathrm{M}\right)$.

According to the $\mathrm{GI}_{50}$ values (Table 2) and the $\mathrm{GI}_{50}$ range plot (Figure 2), we can infer some structure activity relationships. The $\alpha, \beta$-unsaturated ketone derivative 2 is more active than its non-fused derivatives $\mathbf{3 a} \mathbf{a} \mathbf{c}$. We speculate that the presence of the conjugated double bond in $\mathbf{2}$ favors the activity. For the non-fused series, the trend in antiproliferative activity in terms of the exocyclic heteroatom is $\mathrm{N}(\mathbf{3 a})>\mathrm{O}(\mathbf{3 b})>\mathrm{S}(\mathbf{3} \mathbf{c})$. Interestingly, the antiproliferative effects observed for the fused series move in the opposite direction. Thus, $\alpha, \beta$-unsaturated ketone 6 is the least active compound, and the favored exocyclic heteroatom is sulfur $(7 \mathrm{c}>7 \mathbf{b})$.

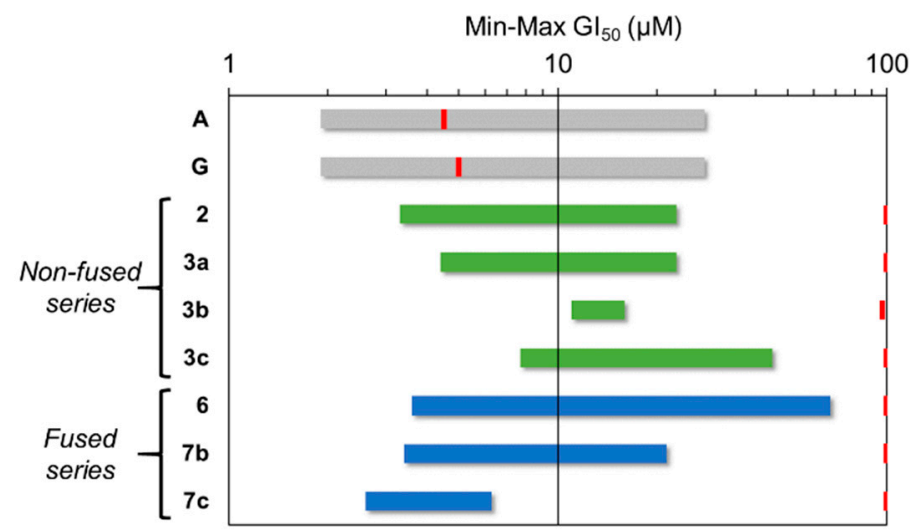

Figure 2. $\mathrm{GI}_{50}$ range plot against tested human solid tumor cell lines (Abiraterone, A; galeterone, G: gray; non-fused pyrimidine steroids: green; fused pyrimidine steroids: blue) and $\mathrm{GI}_{50}$ against human fibroblasts (red).

\subsection{P-Glycoprotein Assay}

Next, we studied if the compounds could be substrates for P-glycoprotein 1 (P-gp). P-gp is an important protein of the cell membrane that pumps xenobiotics out of cells. One of the resistance mechanisms to anticancer drugs involves the overexpression of P-gp by cancer cells, rendering these cancers multidrug resistant. Therefore, it is relevant to know whether compounds are substrates for P-gp or not [18]. As a model to test the effect of P-gp overexpression in our compounds, we used a cell line-based assay. We selected one wild type human lung cancer cell line (SW1573) and its P-gp 
overexpressing variant (SW1573/PGP) [19]. In this test, cells were exposed to the compounds for $48 \mathrm{~h}$ in the absence or the presence of $10 \mu \mathrm{M}$ verapamil, a well-known P-gp inhibitor [20].

Table 3 shows the results expressed as $\mathrm{GI}_{50}$ values and the ratio of $\mathrm{GI}_{50}$ values in the P-gp overexpressing, as well as the wild type cell line, defined as the resistance factor (Rf). Overall, the results indicate that the $\alpha, \beta$-unsaturated ketones 2 and $\mathbf{6}$, and the steroidal pyrimidines $\mathbf{3}$ and 7, are not substrates for P-gp.

Table 3. Antiproliferative activity $\left(\mathrm{GI}_{50}\right)$ against SW1573 and SW1573/PGP cell lines. ${ }^{\mathrm{a}}$

\begin{tabular}{ccccccc}
\hline \multirow{2}{*}{ Compound } & \multicolumn{3}{c}{ w/o Verapamil } & \multicolumn{3}{c}{ w Verapamil } \\
\cline { 2 - 7 } & SW1573 & SW1573/PGP & Rf & SW1573 & SW1573/PGP & Rf \\
\hline $\mathbf{2}$ & $23 \pm 0.2$ & $29 \pm 5.5$ & 1.2 & $20 \pm 2.9$ & $30 \pm 5.9$ & 1.5 \\
3a & $6.9 \pm 0.5$ & $10 \pm 4.2$ & 1.5 & $8.1 \pm 0.7$ & $5.8 \pm 0.1$ & 0.7 \\
3b & $18 \pm 0.9$ & $34 \pm 13$ & 1.9 & $18 \pm 3.4$ & $28 \pm 5.7$ & 1.6 \\
3c & $12 \pm 2.7$ & $38 \pm 6.1$ & 3.2 & $14 \pm 4.4$ & $25 \pm 1.1$ & 1.8 \\
$\mathbf{6}$ & $72 \pm 10$ & $>100.0$ & 1.4 & $71 \pm 9.1$ & $90 \pm 19$ & 1.3 \\
7b & $34 \pm 4.7$ & $49 \pm 4.4$ & 1.5 & $24 \pm 3.0$ & $33 \pm 10$ & 1.4 \\
7c & $9.4 \pm 1.0$ & $16 \pm 1.3$ & 1.7 & $8.1 \pm 0.5$ & $8.5 \pm 1.8$ & 1.1 \\
PTX & $1.5 \pm 0.5$ & $196 \pm 53$ & 128 & $1.6 \pm 0.2$ & $4.2 \pm 0.9$ & 2.6 \\
VB & $0.9 \pm 0.3$ & $2051 \pm 682$ & 2388 & $0.8 \pm 0.2$ & $1.0 \pm 0.5$ & 1.3 \\
\hline
\end{tabular}

a Paclitaxel (PTX) and vinblastine (VB) were used as reference drugs. GI $_{50}$ values are given in $\mu \mathrm{M}$ for compounds 2-3 and 6-7, and in $\mathrm{nM}$ for PTX and VB. Standard deviation was calculated from at least two independent experiments. Rf represents the ratio between GI $_{50}$ values in SW1573/PGP and SW1573 cells.

\section{Materials and Methods}

\subsection{Chemistry}

\subsubsection{General Methods}

Melting points were measured by the open capillary tube method on a Melt-temp apparatus and were not corrected. Optical rotations were measured on a Jasco P-2000 polarimeter (Jasco Inc, Easton, MD, USA). IR spectra were acquired on a Cary 630 FTIR spectrophotometer $\left(\bar{v}_{\text {max }}, \mathrm{cm}^{-1}\right)($ Agilent, Santa Clara, CA, USA). NMR spectra were recorded on a Bruker Ascend $500 \mathrm{MHz}$ instrument (Bruker BioSpin, Rheinstetten, Germany). Chemical shifts are reported in ppm $(\delta)$ and spectra were referenced to the residual protonated solvents: $\mathrm{CDCl}_{3}$ (7.26 and $77.16 \mathrm{ppm}$ ) and $\mathrm{CD}_{3} \mathrm{OD}$ (3.31 and $49.0 \mathrm{ppm}$ ) for ${ }^{1} \mathrm{H}$ and ${ }^{13} \mathrm{C}$ NMR, respectively. Coupling constants $(J)$ are expressed in Hertz $(\mathrm{Hz})$ and ${ }^{1} \mathrm{H}-\mathrm{NMR}$ data are reported as s (singlet), d (doublet), $\mathrm{t}$ (triplet), brs (broad singlet), and $\mathrm{m}$ (multiplet). ${ }^{1} \mathrm{H}$ and ${ }^{13} \mathrm{C}$ signals were assigned using 1D and 2D NMR experiments (DEPT, COSY, HSQC, HMBC, and NOESY). High resolution mass spectra were obtained by EI, ESI, and FAB using a Hewlett Packard 5989 A spectrometer coupled to a Hewlett Packard 5990 II gas chromatographer, a Micromass AutoSpec-Q, and a JEOL JMS-700 MStation mass spectrometer. Column chromatography was performed using Merck silica gel 60 (230-400 mesh). TLC was performed using aluminum pre-coated silica gel plates $60 \mathrm{~F}_{254}$; spots were visualized by UV light and charring with $5 \% \mathrm{H}_{2} \mathrm{SO}_{4}$ (aq), $10 \%$ vanillin in EtOH containing $1 \%$ of $\mathrm{H}_{2} \mathrm{SO}_{4}$, or with $0.1 \%$ ninhydrin in $\mathrm{EtOH}$.

\subsection{2. (E)-21-benzyliden-3ß-hydroxypregn-5-en-20-one (2)}

To a solution of $\mathbf{1}(0.35 \mathrm{~g}, 1 \mathrm{mmol})$ in EtOH $(5 \mathrm{~mL})$ was added benzaldehyde $(0.1 \mathrm{~mL}, 1 \mathrm{mmol})$ and $\mathrm{KOH}(10 \mathrm{~mL}, 10 \%$ in $\mathrm{EtOH})$. The mixture was stirred at room temperature until the formation of the $\alpha$, $\beta$-unsaturated ketone [15]. Then, the reaction mixture was extracted with $\mathrm{CH}_{2} \mathrm{CI}_{2}(3 \times 25 \mathrm{~mL})$. The combined organic phases were washed with brine $(3 \times 20 \mathrm{~mL})$ and water $(1 \times 20 \mathrm{~mL})$, and then dried over anhydrous $\mathrm{MgSO}_{4}$ and concentrated to dryness. The crude was purified by flash column chromatography (9:1 hexane-AcOEt) to afford product 2 as a white solid. Yield $98 \% ; \mathrm{mp} .110-112{ }^{\circ} \mathrm{C}$; $[\alpha]_{\mathrm{D}}^{20}-0.96\left(\mathrm{c} 1, \mathrm{CHCl}_{3}\right)$. IR $\left(\mathrm{cm}^{-1}\right): 3320(\mathrm{OH}), 2939$ (CH aliphatic), $2000(\mathrm{CH}$ aromatic), $1679(\mathrm{C}=\mathrm{O}$, 
$\alpha, \beta$-unsaturated ketone), $1603(\mathrm{C}=\mathrm{C}), 1053(\mathrm{CO}) .{ }^{1} \mathrm{H}-\mathrm{NMR} \delta: 0.66$ (s, 3H, $\left.\mathrm{CH}_{3}-18\right), 1.02\left(\mathrm{~s}, 3 \mathrm{H}, \mathrm{CH}_{3}-19\right)$, $2.88(\mathrm{t}, 1 \mathrm{H}, J=9.0 \mathrm{~Hz}, \mathrm{H}-17), 3.55(\mathrm{~m}, 1 \mathrm{H}, \mathrm{H}-3), 5.39(\mathrm{~d}, 1 \mathrm{H}, J=5.2 \mathrm{~Hz}, \mathrm{H}-6), 6.82(\mathrm{~d}, 1 \mathrm{H}, J=16.0 \mathrm{~Hz}$, H-21), 7.40 (m, 3H, H-3' , H-4', H-5') 7.59 (m, 3H, H-2' , H-6' , H-22') ${ }^{13}{ }^{\mathrm{C}-N M R}$ 8: 13.4 (C-18), 19.4 (C-19), 21.1 (C-11), 22.7 (C-15), 24.7 (C-16), 31.8 (C-7), 36.5 (C-2), 37.2 (C-8), 39.1 (C-1), 42.2 (C-10), 44.0 (C-12), 45.0 (C-4), 50.0 (C-13), 57.2 (C-9), 62.3 (C-14), 62.5 (C-17), 71.7 (C-3), 121.4 (C-6), 126.8 (C-21), 128.2 (C-2' and C-6'), 128.9 (C-3' and C-5'), $130.3\left(\mathrm{C}-4^{\prime}\right), 134.8$ (C-1') 140.7 (C-5), 141.5 (C-22), 200.5 (C-20). HRMS-FAB: $(m / z)[\mathrm{M}+\mathrm{H}]^{+}$calculated for $\mathrm{C}_{28} \mathrm{H}_{36} \mathrm{O}_{2}: 404.2715$, found: 404.2786 .

\subsubsection{General Procedure for the Preparation of $3 a-c$}

To a solution of $2(0.1 \mathrm{~g}, 1 \mathrm{mmol})$ in dry $\mathrm{BuOH}(5 \mathrm{~mL})$ was added the 1,3-binucleophile (thiourea, urea, or guanidine hydrochloride, $2.5 \mathrm{mmol})$ and $t$-BuOK solution $1 \mathrm{M}$ in THF $(0.99 \mathrm{~mL}, 8 \mathrm{mmol})$. The mixture was refluxed for $7-8 \mathrm{~h}$ and then extracted with $\mathrm{CH}_{2} \mathrm{Cl}_{2}(3 \times 20 \mathrm{~mL})$. The combined organic phases were washed with brine $(1 \times 20 \mathrm{~mL})$, dried over $\mathrm{MgSO}_{4}$ and concentrated to dryness. The crude was purified by flash column chromatography (7:3 hexane-AcOEt) to afford $\mathbf{3 a - c}$.

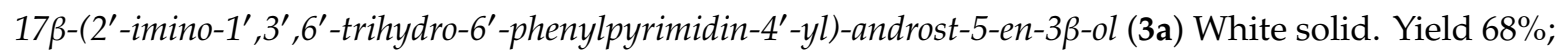
mp: $128^{\circ} \mathrm{C} ;[\alpha]_{\mathrm{D}}^{20}-0.96\left(\mathrm{c} 0.11, \mathrm{CHCl}_{3}\right)$. IR $\left(\mathrm{cm}^{-1}\right)$ : $3334(\mathrm{C}=\mathrm{NH}), 3320(\mathrm{OH}), 2939$ (C-H aliphatic),

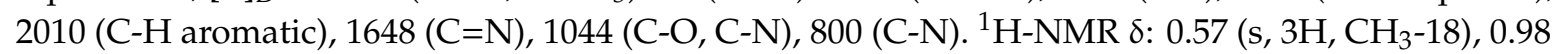
(s, 3H, $\left.\mathrm{CH}_{3}-19\right), 3.52(\mathrm{~m}, 1 \mathrm{H}, \mathrm{H}-3), 5.27\left(\mathrm{~d}, 2 \mathrm{H}, J=15 \mathrm{~Hz}, \mathrm{H}-5^{\prime}\right), 5.36(\mathrm{~d}, 1 \mathrm{H}, J=5.2 \mathrm{~Hz}, \mathrm{H}-6), 6.79$ (sa, 1H, H-3'), 6.59 (s, 1H, H-6'), 6.78 (brs, 1H, NH-1'), 6.87 (brs, 1H, NH-2'), 7.27 (brs, NH-3'), 7.44 (m,

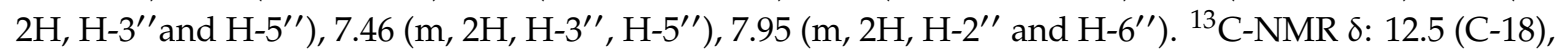
14.8 (C-11), 18.9 (C-19), 24.3 (C-15), 24.6 (C-2), 27.6 (C-4'), 31.5 (C-16), 32.1 (C-7), 33.6 (C-1), 36.1.(C-10), 36.8 (C-8), 37.6 (C-4), 41.8 (C-4), 44.5 (C-13), 49.8 (C-5), 56.4 (C-14), 57.5 (C-6'), 65.3 (C-17), 71.1 (C-3), $107.0\left(\mathrm{C}-5^{\prime}\right) 120.1(\mathrm{C}-6), 127.0\left(\mathrm{C}-2^{\prime \prime}\right), 128.6\left(\mathrm{C}-3^{\prime \prime}\right.$ and C-6" $\left.{ }^{\prime \prime}\right), 130.1\left(\mathrm{C}-4^{\prime \prime}\right), 137.8\left(\mathrm{C}-5^{\prime}\right), 137.9\left(\mathrm{C}-1^{\prime \prime}\right)$, $131.5\left(\mathrm{C}-6^{\prime}\right), 140.8\left(\mathrm{C}-4^{\prime}\right), 140.9(\mathrm{C}-5), 162.5\left(\mathrm{C}-2^{\prime}\right)$. HRMS-FAB: $(\mathrm{m} / \mathrm{z})[\mathrm{M}+\mathrm{H}]^{+}$calculated $\mathrm{C}_{29} \mathrm{H}_{39} \mathrm{~N}_{3} \mathrm{O}$ : 444.1015, found: 444.3015 .

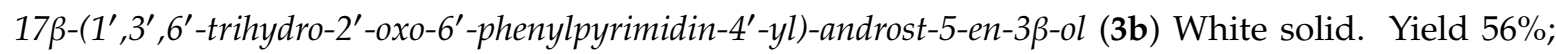
mp: $108-110^{\circ} \mathrm{C} ;[\alpha]_{\mathrm{D}}{ }^{20}-0.96\left(\mathrm{c} 0.11, \mathrm{CHCl}_{3}\right)$. IR $\left(\mathrm{cm}^{-1}\right)$ : $3320(\mathrm{OH}), 2929$ (C-H aliphatic), 2010 (C-H aromatic), $1643(\mathrm{C}=\mathrm{O}), 1047(\mathrm{C}-\mathrm{O}), 771(\mathrm{C}-\mathrm{N}) .{ }^{1} \mathrm{H}-\mathrm{NMR} \delta: 0.74\left(\mathrm{~s}, 3 \mathrm{H}, \mathrm{CH}_{3}-18\right), 0.82\left(\mathrm{~s}, 3 \mathrm{H}, \mathrm{CH}_{3}-19\right)$, $3.56(\mathrm{~m}, 1 \mathrm{H}, \mathrm{H}-3), 5.35(\mathrm{~d}, 1 \mathrm{H}, J=5.2 \mathrm{~Hz}, \mathrm{H}-6), 6.37\left(\mathrm{~d}, 1 \mathrm{H}, J=16 \mathrm{~Hz}, \mathrm{H}-5^{\prime}\right), 6.59\left(\mathrm{~d}, 1 \mathrm{H}, J=16 \mathrm{~Hz}, \mathrm{H}-6^{\prime}\right)$, $7.18\left(\mathrm{~d}, 2 \mathrm{H}, J=8 \mathrm{~Hz}, \mathrm{H}-2^{\prime \prime}\right.$ and $\left.\mathrm{H}-6^{\prime \prime}\right), 7.24\left(\mathrm{~m}, 1 \mathrm{H}\right.$ and $\left.\mathrm{H}-4^{\prime}\right), 7.31\left(\mathrm{~m}, 2 \mathrm{H}, \mathrm{H}-3^{\prime \prime}\right.$ and $\left.\mathrm{H} 5^{\prime \prime}\right) .{ }^{13} \mathrm{C}-\mathrm{NMR} \delta$ : 12.3 (C-19), 13.6 (C-18), 15.9 (C-11), 21.6 (C-15), 23.5 (C-2), 27.6 (C-4'), 28.5 (C-16), 31.6 (C-7), 33.1 (C-1), 35.1.(C-10), 35.9 (C-8), 36.6 (C-4), 37.8 (C-12), 38.3 (C-13), 44.2 (C-5), 49.7 (C-14), 53.6 (C-6'), 60.6 (C-17), $71.6(\mathrm{C}-3), 120.5(\mathrm{C}-6), 126.1\left(\mathrm{C}-2^{\prime \prime}\right.$ and $\left.\mathrm{C}-6^{\prime \prime}\right), 127.6\left(\mathrm{C}-4^{\prime \prime}\right), 128.9\left(\mathrm{C}-3^{\prime \prime}\right.$ and $\left.\mathrm{C}-5^{\prime \prime}\right), 128.9\left(\mathrm{C}-5^{\prime}\right), 131.5$ $\left(\mathrm{C}-6^{\prime}\right), 138.3\left(\mathrm{C}-1^{\prime \prime}\right), 138.3\left(\mathrm{C}-1^{\prime \prime}\right), 140.1(\mathrm{C}-5), 174.6 .5$ (C-2'). HRMS-FAB: $(m / z)[\mathrm{M}+\mathrm{H}]^{+}$calculated $\mathrm{C}_{29} \mathrm{H}_{38} \mathrm{~N}_{2} \mathrm{O}_{2}$ : 446.2933, found: 446.6350 .

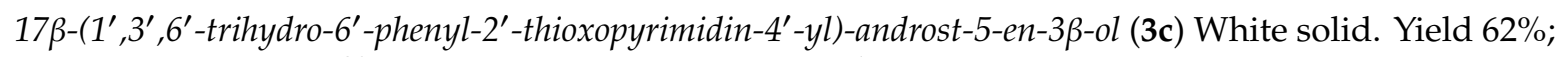
mp: $208-210^{\circ} \mathrm{C} ;[\alpha]_{\mathrm{D}}{ }^{20}-37.99$ (c 0.11, $\left.\mathrm{CHCl}_{3}\right)$. IR $\left(\mathrm{cm}^{-1}\right)$ : $3324(\mathrm{OH}), 2939$ (C-H aliphatic), 2015 (C-H aromatic), 1059 (C=S), 755 (C-N). ${ }^{1} \mathrm{H}-\mathrm{NMR} \delta: 0.55\left(\mathrm{~s}, 3 \mathrm{H}, \mathrm{CH}_{3}-18\right), 0.93\left(\mathrm{~s}, 3 \mathrm{H}, \mathrm{CH}_{3}-19\right), 3.46(\mathrm{~m}, 1 \mathrm{H}$, H-3), 4.67 (sa, 1H, H-5'), 5.10 (sa, 1H, H-6'), 5.26 (d, 1H, J = 5.2 Hz, H-6) 6.63 (sa, 1H, N-H3'), 7.00 (sa, 1H, N-H1'), 7.22 (m, 5H, H-aromatic). ${ }^{13} \mathrm{C}-\mathrm{NMR}$ 8: 13.0 (C-18), 19.4 (C-19), 19.8 (C-11), 21.1 (C-15), 24.0 (C-2), 24.0 (C-4'), 29.9 (C-16), 31.8 (C-7), 32.3 (C-1), 36.7 (C-15), 37.4 (C-10), 36.5 (C-8), 37.1 (C-4), 38.4 (C-12), 42.1 (C-13), 49.8 (C-9), 55.8 (C-17), 56.9 (C-6'), 71.6 (C-3), 99.9 (C-5'), 121.2 (C-6), 126.8 $\left(\mathrm{C}-2^{\prime \prime}\right.$ and $\left.\mathrm{C}-6^{\prime \prime}\right), 134.2\left(\mathrm{C}-4^{\prime}\right), 129.0\left(\mathrm{C}-3^{\prime}\right.$ and $\left.\mathrm{C}^{\prime \prime}{ }^{\prime \prime}\right), 134.2\left(\mathrm{C}-1^{\prime \prime}\right), 142.8\left(\mathrm{C}-4^{\prime \prime}\right), 140.9(\mathrm{C}-5), 174.3\left(\mathrm{C}-2^{\prime}\right)$. HRMS-FAB: $(m / z)[\mathrm{M}+\mathrm{H}]^{+}$calculated $\mathrm{C}_{29} \mathrm{H}_{38} \mathrm{~N}_{2} \mathrm{OS}: 462.2705$, found: 462.6960 .

\subsection{4. (25R)-furosta-5,20(22)-diene-3 $\beta, 26$-diyl Diacetate (5)}

To a solution of diosgenin $(4,0.83 \mathrm{~g}, 2.0 \mathrm{mmol})$ in $\mathrm{CH}_{2} \mathrm{Cl}_{2}(10 \mathrm{~mL})$ were sequentially added $\mathrm{BF}_{3} \cdot \mathrm{OEt}_{2}(1.0 \mathrm{~mL}, 7.96 \mathrm{mmol})$ and freshly prepared acetic trifluoracetic anhydride $(4.7 \mathrm{~mL}, 21.8 \mathrm{mmol})$. The mixture was magnetically stirred at room temperature and monitored by TLC until complete 
conversion of the starting material (approximately $5 \mathrm{~min}$ ). The mixture was poured over ground ice $(20 \mathrm{~g})$ and vigorously shaken. The crude product was washed with saturated solution of $\mathrm{NaHCO}_{3}$ $(3 \times 20 \mathrm{~mL})$ and brine $(3 \times 20 \mathrm{~mL})$. The organic phase was dried using anhydrous $\mathrm{MgSO}_{4}$ and concentrated to dryness. The crude was purified by flash chromatography ( $8: 2$ hexane-AcOEt) to give 5 as a white solid. Yield 93\%; mp: $59-60{ }^{\circ} \mathrm{C} ;[\alpha]_{\mathrm{D}}{ }^{20}-27.4\left(\mathrm{c} 1.09, \mathrm{CHCl}_{3}\right)$. IR $\left(\mathrm{cm}^{-1}\right): 2941(\mathrm{C}-\mathrm{H}$ aliphatic), 1727 (C=O ester), 1661 (C=C), 1231 (O-C-O), 1027 (C-O). ${ }^{1} \mathrm{H}-\mathrm{NMR}$ 8: 0.69 (s, 3H, CH -18 ), $0.94\left(\mathrm{~d}, 3 \mathrm{H}, J=7.2 \mathrm{~Hz}, \mathrm{CH}_{3}-27\right), 1.03$ (s, 3H, $\left.\mathrm{CH}_{3}-19\right), 1.58$ (s, 3H, $\left.\mathrm{CH}_{3}-21\right), 2.02$ (s, 3H, $\mathrm{CH}_{3} \mathrm{COO}-3$ ), $2.04\left(\mathrm{~s}, 3 \mathrm{H}, \mathrm{CH}_{3} \mathrm{COO}-26\right), 2.47(\mathrm{~d}, 1 \mathrm{H}, J=8.5 \mathrm{~Hz}, \mathrm{H}-17), 3.87\left(\mathrm{dd}, 1 \mathrm{H}, J_{26 \alpha, 26 \beta}=10.6 \mathrm{~Hz}, J_{26 \alpha, 25}=5.6 \mathrm{~Hz}\right.$, $\mathrm{H}-26 \alpha), 3.93\left(\mathrm{dd}, 1 \mathrm{H}, J_{26 \beta, 26 \alpha}=10.6 \mathrm{~Hz}, J_{26 \beta, 25}=5.6 \mathrm{~Hz}, \mathrm{H}-26 \beta\right), 4.58(\mathrm{~m}, 1 \mathrm{H}, \mathrm{H}-3), 4.72(\mathrm{~m}, 1 \mathrm{H}, \mathrm{H}-16)$, $5.36(\mathrm{~d}, 1 \mathrm{H}, J=4 \mathrm{~Hz}, \mathrm{H}-6) .{ }^{13} \mathrm{C}-\mathrm{NMR}$ 8: 11.7 (C-21), 14.0 (C-18), 16.8 (C-27), 9.4 (C-19), 21.0 (C-11), 21.5 ( $\left.\mathrm{CH}_{3} \mathrm{COO}-3\right), 23.2$ (C-23), 27.7 (C-2), 30.8 (C-24), 31.2 (C-8), 32.1 (C-7), 32.1 (C-25), 34.2 (C-15), 36.6 (C-10), 37.0 (C-1), 38.1 (C-4), 39.4 (C-12), 43.2 (C-13), 49.9 (C-9), 54.9 (C-14), 64.1 (C-17), 69.7 (C-26), 73.7 (C-3), 84.2 (C-16), 103.6 (C-20), 122.1 (C-6),139.4 (C-5), 151.1 (C-22), $170.2\left(\mathrm{CH}_{3} \mathrm{COO}-3\right), 171.2$ $\left(\mathrm{CH}_{3} \mathrm{COO}-26\right)$. HRMS-FAB: $(\mathrm{m} / \mathrm{z})[\mathrm{M}+\mathrm{H}]^{+}$calculated $\mathrm{C}_{31} \mathrm{H}_{46} \mathrm{O}_{5}: 498.33$, found: 498.69.

\subsubsection{0-Oxopregna-5,16-dien-3 $\beta$-yl Acetate (6)}

A solution of pseudodiosgenin diacetate (5) $(2.0 \mathrm{~g}, 4 \mathrm{mmol})$ in $\mathrm{CH}_{2} \mathrm{CI}_{2}(8 \mathrm{~mL})$, acetic acid $(8 \mathrm{~mL})$ and water $(1 \mathrm{~mL})$ was cooled to $0{ }^{\circ} \mathrm{C}$. Then, a solution of $\mathrm{CrO}_{3}(0.84 \mathrm{~g}, 8.5 \mathrm{mmol})$ in water $(1.2 \mathrm{~mL})$ and acetic acid $(0.4 \mathrm{~mL})$ was added dropwise. The mixture was magnetically stirred at room temperature and monitored by TLC until disappearance of the starting material $(4 \mathrm{~h})$. The mixture was extracted with $\mathrm{CH}_{2} \mathrm{Cl}_{2}(3 \times 20 \mathrm{~mL})$ and then treated with a saturated solution of $\mathrm{NaCl}$ in stirred for $15 \mathrm{~min}$. The mixture was extracted with $\mathrm{CH}_{2} \mathrm{Cl}_{2}(2 \times 20 \mathrm{~mL})$, the organic phases were washed with water $(3 \times 20 \mathrm{~mL})$, dried over $\mathrm{MgSO}_{4}$ and concentrated to dryness. The crude was maintained under reflux in acetic acid and monitored with TLC until observation of a more polar compound. After completion of the reaction, water was added and neutralized with a saturated solution of $\mathrm{NaHCO}_{3}$. The organic phase was dried over $\mathrm{MgSO}_{4}$ and concentrated to dryness. The crude was purified by flash column chromatography (9:1 hexane-AcOEt) to give compound 6 as a white solid. Yield $82 \%$; mp: $108-110{ }^{\circ} \mathrm{C}$; $[\alpha]_{\mathrm{D}}^{20}+0.86\left(\mathrm{c} 1.02, \mathrm{CHCl}_{3}\right)$. IR $\left(\mathrm{cm}^{-1}\right): 3320(\mathrm{OH}), 2939$ (C-H aliphatic), $1700(\mathrm{C}=\mathrm{O} \alpha, \beta$-unsaturated ketone), 1027 (C-O). ${ }^{1} \mathrm{H}-\mathrm{NMR} \delta: 0.92\left(\mathrm{~s}, 3 \mathrm{H}, \mathrm{CH}_{3}-18\right), 1.06$ (s, 3H, $\left.\mathrm{CH}_{3}-19\right), 2.04$ (s, 3H, $\left.\mathrm{CH}_{3} \mathrm{COO}-3\right) 2.27$ $\left(\mathrm{s}, 3 \mathrm{H}, \mathrm{CH}_{3}-21\right), 4.55(\mathrm{~m}, 1 \mathrm{H}, \mathrm{H}-3), 5.33(\mathrm{~d}, 1 \mathrm{H}, J=4 \mathrm{~Hz}, \mathrm{H}-6), 6.67(\mathrm{~d}, 1 \mathrm{H}, J=4 \mathrm{~Hz}, \mathrm{H}-16) .{ }^{13} \mathrm{C}-\mathrm{NMR} \delta$ : 15.6 (C-18), 19.1 (C-19), 20.5 ( $\left.\mathrm{CH}_{3} \mathrm{COO}-3\right), 21.4$ (C-11), 27.1 (C-21), 27.6 (C-2), 30.0 (C-7), 31.4 (C-15), 32.2 (C-12), 34.5 (C-8), 36.7 (C-4), 46.0 (C-13), 50.2 (C-9), 56.2 (C-14), 73.6 (C-3), 121.9 (C-6), 140.0 (C-5), 144.4 (C-16), $155.2(\mathrm{C}-17), 170.5\left(\mathrm{CH}_{3} \mathrm{COO}-3\right), 196.8(\mathrm{C}-20)$. HRMS-FAB: $(\mathrm{m} / \mathrm{z})[\mathrm{M}+\mathrm{H}]^{+}$calculated $\mathrm{C}_{21} \mathrm{H}_{30} \mathrm{O}_{2}$ : 356.2351, found: 356.5060 .

\subsubsection{General Procedure for the Preparation of $7 \mathbf{a}-\mathbf{c}$}

Compound 6 (0.2 g, $0.63 \mathrm{mmol})$ was dissolved in an alcoholic solution of $\mathrm{KOH}(1 \%)$ and 1,3-binucleophile was added (thiourea, urea, or guanidine hydrochloride, $1.2 \mathrm{mmol}$ ). The mixture was maintained under reflux for 8-14 $\mathrm{h}$ and monitored by TLC until disappearance of the starting material. Then, grinded ice was added and extracted with $\mathrm{CH}_{2} \mathrm{CI}_{2}(3 \times 20 \mathrm{~mL})$. The combined organic phase was washed with brine $(2 \times 20 \mathrm{~mL})$ and water $(1 \times 20 \mathrm{~mL})$, dried over $\mathrm{MgSO}_{4}$ and concentrated to dryness under vacuum. The crude was purified by flash column chromatography (7:3 hexane-AcOEt).

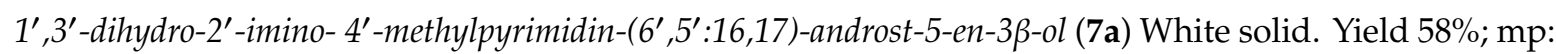
$108-110^{\circ} \mathrm{C} ;[\alpha]_{\mathrm{D}}{ }^{20}-0.96\left(\mathrm{c} 0.11, \mathrm{CHCl}_{3}\right)$. IR $\left(\mathrm{cm}^{-1}\right)$ : $3320(\mathrm{OH}), 3187(\mathrm{C}-\mathrm{N}), 2939(\mathrm{C}-\mathrm{H}), 1709(\mathrm{C}=\mathrm{N})$, 1042 (C-O), 750 (C-N). ${ }^{1} \mathrm{H}-\mathrm{NMR}$ 8: $0.93\left(\mathrm{~s}, 3 \mathrm{H}, \mathrm{CH}_{3}-18\right), 1.18\left(\mathrm{~s}, 3 \mathrm{H}, \mathrm{CH}_{3}-19\right), 1.91\left(\mathrm{~s}, 3 \mathrm{H}, \mathrm{CH}_{3}-4^{\prime}\right), 3.58$ (m, 1H, H-3), 3.98 (m, 1H, H-16), 5.30 (d, 1H, J = 4 Hz, H-6), 6.14 (s, 1H, NH-1'), 6.81 (s, 1H, NH-3'), 7.29 (sa, 1H, NH-2'). ${ }^{13} \mathrm{C}$ RMN 8: 14.0 (C-4") $) 16.9$ (C-19), 19.2 (C-18), 20.8 (C-11), 29.3 (C-1), 29.6 (C-7), 31.4 (C-8), 33.9. (C-15), 35.9 (C-12), 36.6 (C-10), 41.8 (C-4), 42.1 (C-12), 43.5 (C-13), 50.2 (C-9), 53.2 (C-16), 
55.2 (C-14), 71.3 (C-3), 120,8 (C-6), 120.8 .5 (C-4'), 132.2 (C-17), 141.2 (C-5), 174.5 (C-2'). HRMS-FAB: $(\mathrm{m} / \mathrm{z})[\mathrm{M}+\mathrm{H}]^{+}$calculated $\mathrm{C}_{22} \mathrm{H}_{32} \mathrm{~N}_{2} \mathrm{OS}: 355.5624$, found: 356.5260 .

$1^{\prime}, 3^{\prime}$-dihydro-4'-methyl-2'-oxopyrimidin- $\left(6^{\prime}, 5^{\prime}: 16,17\right)$-androst-5-en-3 $\beta$-ol (7b) White solid. Yield $52 \%$; mp: $163-164{ }^{\circ} \mathrm{C} ;[\alpha]_{\mathrm{D}}{ }^{20}-0.96$ (c 0.11, $\left.\mathrm{CHCl}_{3}\right)$. IR $\left(\mathrm{cm}^{-1}\right)$ : $3307(\mathrm{OH}), 2927$ (C-H aliphatic), 1647 (C=O), 1047 (C-O), $771(\mathrm{C}-\mathrm{N}) .{ }^{1} \mathrm{H}-\mathrm{NMR} \delta: 0.85\left(\mathrm{~s}, 3 \mathrm{H}, \mathrm{CH}_{3}-18\right), 0.97\left(\mathrm{~s}, 3 \mathrm{H}, \mathrm{CH}_{3}-19\right), 1.78\left(\mathrm{~s}, 3 \mathrm{H}, \mathrm{CH}_{3}-4^{\prime}\right), 3.45$ (m, $1 \mathrm{H}, \mathrm{H}-3), 4.35$ (d, 1H, $J=8 \mathrm{~Hz}, \mathrm{H}-16), 5.35$ (d, 1H, $J=4 \mathrm{~Hz}, \mathrm{H}-6), 5.75$ (s, 1H, NH-1'), 6.79 (s, 1H, NH-3'). ${ }^{13}$ C-NMR 8: 15.2 (C-4'), 16.4 (C-19), 19.4 (C-18), 20,4 (C-11), 31.1 (C-1), 31.2 (C-7), 31.6 (C-8), 32.6 (C-15), 35.5 (C-12), 36.2 (C-10), 36.5 (C-4), 36.8 (C-12), 41.6 (C-13), 49.7 (C-9), 52.3 (C-16), 54.5 (C-14), 65.6 (C-3), 120.6 (C-6), $121.4\left(\mathrm{C}-4^{\prime}\right), 123.0(\mathrm{C}-17), 140.8(\mathrm{C}-5), 157.4\left(\mathrm{C}-2^{\prime}\right)$. HRMS-FAB: $(\mathrm{m} / \mathrm{z})[\mathrm{M}+\mathrm{H}]^{+}$calculated $\mathrm{C}_{22} \mathrm{H}_{32} \mathrm{~N}_{2} \mathrm{OS}$ : 356.2264, found: 356.5110 .


mp: $208-210{ }^{\circ} \mathrm{C} ;[\alpha]_{\mathrm{D}}{ }^{20}-37.99$ (c 1.02, $\mathrm{CHCl}_{3}$ ). IR $\left(\mathrm{cm}^{-1}\right)$ : $3320(\mathrm{OH}), 2939$ (C-H aliphatic), 1201 (C=S), 1042 (C-O), 750 (C-N). ${ }^{1} \mathrm{H}-\mathrm{NMR} \delta: 0.89$ (s, 3H, CH $\left.\mathrm{CH}_{3}-18\right), 1.02$ (s, 3H, $\left.\mathrm{CH}_{3}-19\right), 1.87$ (s, 3H, $\left.\mathrm{CH}_{3}-4^{\prime}\right), 3.46$ (m, 1H, H-3), 4.20 (d, 1H, J = 8 Hz, H-16), 5.28 (d, 1H, J = 4 Hz, H-6), 6.87 (s, 1H, H-1'), 7.87 (s, 1H, H-3'). ${ }^{13}$ C-NMR 8: 15.2 (C-4'), 16.4 (C-19), 19.5 (C-18), 20.6 (C-11), 31.2 (C-1), 31.3 (C-7), 31.4 (C-8), 32.4 (C-15), 35.8 (C-12), 36.6 (C-10), 37.0 (C-4), 42.1 (C-12), 43.7 (C-13), 49.5 (C-9), 53.2 (C-16), 54.5 (C-14), 71.3 (C-3), 120,8 (C-6), 121.5 (C-4'), 122.6 (C-17), 140,8 (C-5), 176.18 (C-2'). HRMS-FAB: $(m / z)[M+]^{+}$ calculated $\mathrm{C}_{22} \mathrm{H}_{32} \mathrm{~N}_{2} \mathrm{OS}: 372.2235$, found: 372.2269 .

1H- and 13C-NMR charts are available in Supplementary Materials.

\subsection{Biological Tests}

\subsubsection{Cell Lines and Growth Conditions}

The human solid tumor cell lines A549 (non-small cell lung), HBL-100 (breast), and HeLa (cervix), SW1573 (non-small cell lung), and its P-gp overexpressing variant (SW1573/Pgp), T-47D (breast), and WiDr (colon) were used in this study. These cell lines used in this study were kindly provided by Dr. Godefridus J. Peters (Cancer Center Amsterdam, Vrije Universiteit, Amsterdam, The Netherlands). BJ-hTERT human fibroblast cells were given by Dr. Raimundo Freire (Universidad de La Laguna, Canary Islands). All cells were grown in RPMI 1640 supplemented with $1 \mathrm{mM}$ glutamine, 5\% FBS and antibiotics. Cells were grown at $37{ }^{\circ} \mathrm{C}$ in a humidified atmosphere of $5 \% \mathrm{CO}_{2}$ and maintained at low passage.

\subsubsection{Growth Inhibition Assays}

The antiproliferative activity was tested in vitro against human cancer cells using the protocol of the National Cancer Institute (NCI) of the USA16 with minor modifications [21]. The following densities (cells per well) were used: 2500 (A549, HBL-100, HeLa and SW1573), 5000 (T-47D, WiDr and SW1573/PGP), and 7000 (BJ-hTERT). Samples for testing were dissolved initially in DMSO at $40 \mathrm{mM}$, i.e., 400 times the maximum test concentration. Abiraterone and galeterone were used as reference drugs for antiproliferative tests, verapamil was used as a P-gp transport inhibitor in SW1573/Pgp experiments, and their stock solutions were prepared in DMSO at $40 \mathrm{mM}$. Paclitaxel and vinblastine were used as positive controls in SW1573/Pgp experiments and were initially dissolved in DMSO at $4 \mathrm{mM}$. For each test compound, the cells were exposed to serial decimal dilutions in the range of $0.001-100 \mu \mathrm{M}$ for a period of $48 \mathrm{~h}$. Cell culture medium containing verapamil was prepared by adding the final concentration of verapamil of $10 \mu \mathrm{M}$. For each product $\mathrm{GI}_{50}$ values were calculated according to the NCI formulas.

\section{Conclusions}

Pregnenolone acetate (1) and diosgenin (4) were efficiently transformed into $\alpha, \beta$-unsaturated ketones $\mathbf{2}$ and $\mathbf{6}$, respectively. These intermediates were treated with 1,3-binucleophiles (guanidine, 
urea or thiourea) to produce steroidal pyrimidines 3 and 7, respectively. Antiproliferative activities were found for all tested compounds with good selectivity towards cancer cells. Furthermore, these compounds did not act as P-glycoprotein substrates, thus avoiding the rise of drug resistance. Overall, fused steroidal pyrimidinethione 7c could be selected as the lead for further testing due to its strong antiproliferative activities within the low micromolar range. In summary, we have shown that the natural products reservoir represents a fast and reliable source for chemical scaffolds that can be transformed in a few reaction steps into pharmacologically relevant chemical entities. This work definitively establishes a versatile platform for the synthesis of a number of bioactive steroidal pyrimidines with the possibility of even further accessing the unnatural analogues of these steroidal pyrimidines using similar chemistry. The combined findings indicate that steroidal pyrimidines offer a source of novel bioactive molecules that could be used in the treatment of human diseases.

Supplementary Materials: The following are available online at http://www.mdpi.com/1420-3049/24/20/3676/s1 containing ${ }^{1} \mathrm{H}$ - and ${ }^{13} \mathrm{C}-\mathrm{NMR}$ charts.

Author Contributions: S.M.-S. and J.M.P. conceived and designed the experiments; A.C.-P., A.R.-L. performed the chemical and spectroscopic experiments; elucidation and analysis of data, J.L.V.-B., P.M.-M. and S.M.-R.; J.M.P. and A.P. performed the biological experiments; writing-review and editing, J.M.P. and P.M.-M.; all authors discussed the results and commented on the manuscript.

Funding: This research was funded by CONACYT-México, grant 240329 and Spanish Government project PGC2018-094503-B-C22 (MCIU/AEI/FEDER, UE).

Acknowledgments: The authors thank CONACYT-México for a scholarship to A.C.-P., and financial support (grant 240329 to SMS). A.P. and J.M.P. thank the Spanish Government for financial support through project PGC2018-094503-B-C22 (MCIU/AEI/FEDER, UE).

Conflicts of Interest: The authors declare no conflict of interest.

\section{References}

1. Newman, D.J.; Cragg, G.M. Natural Products as Sources of New Drugs from 1981 to 2014. J. Nat. Prod. 2016, 79, 629-661. [CrossRef] [PubMed]

2. Carbone, A.; Parrino, B.; Cusimano, M.G.; Spanò, V.; Montalbano, A.; Barraja, P.; Schillaci, D.; Cirrincione, G.; Diana, P.; Cascioferro, S. New thiazole nortopsentin analogues inhibit bacterial biofilm formation. Mar. Drugs 2018, 16, 274. [CrossRef] [PubMed]

3. Spanò, V.; Attanzio, A.; Cascioferro, S.; Carbone, A.; Montalbano, A.; Barraja, P.; Tesoriere, L.; Cirrincione, G.; Diana, P.; Parrino, B. Synthesis and antitumor activity of new thiazole nortopsentin analogs. Mar. Drugs 2016, 14, 226. [CrossRef] [PubMed]

4. Vitaku, E.; Smith, D.T.; Njardarson, J.T. Analysis of the structural diversity, substitution patterns, and frequency of nitrogen heterocycles among U.S. FDA approved pharmaceuticals. J. Med. Chem. 2014, 57, 10257-10274. [CrossRef] [PubMed]

5. Shamsuzzaman; Dar, A.M.; Yaseen, Z.; Alam, K.; Hussain, A.; Gatoo, M.A. Steroidal pyrimidines; Synthesis, characterization, molecular docking studies with DNA and vitro cytotoxicity. J. Mol. Struct. 2013, 1045, $62-71$.

6. Shamsuzzaman; Dar, A.M.; Tabassum, S.; Zaki, M.; Khan, Y.; Sohail, A.; Gatoo, M.A. DNA binding, docking studies, artificial nuclease activity and in vitro cytotoxicity of newly synthesized steroidal $1 \mathrm{H}$-pyrimidines. C. R. Chimie 2014, 17, 359-369. [CrossRef]

7. Dar, A.M.; Rah, B.; Mir, S.; Nabi, R.; Shamsuzzaman; Gatoo, M.A.; Mashrai, A.; Khand, Y. DNA binding, artificial nuclease activity and cytotoxic studies of newly synthesized steroidal pyrimidines. Int. J. Biol. Macromol. 2018, 111, 52-61. [CrossRef] [PubMed]

8. Mohareb, R.M.; Al-Omran, F.; Azzam, R.A. Heterocyclic ring extension of estrone: Synthesis and cytotoxicity of fused pyran, pyrimidine and thiazole derivatives. Steroids 2014, 84, 46-56. [CrossRef]

9. Yu, B.; Shi, X.-J.; Zheng, Y.-F.; Fang, Y.; Zhang, E.; Yu, D.-Q.; Liu, H.-M. A novel [1,2,4] triazolo [1,5-a] pyrimidine-based phenyl-linked steroid dimer: Synthesis and its cytotoxic activity. Eur. J. Med. Chem. 2013, 69, 323-330. [CrossRef] 
10. Ali, A.; Asif, M.; Alam, P.; Alam, J.M.; Sherwani, A.M.; Khan, H.R.; Ahmad, S.; Shamsuzzaman. DFT/B3LYP calculations, in vitro cytotoxicity and antioxidant activities of steroidal pyrimidines and their interaction with HSA using molecular docking and multispectroscopic techniques. Bioorg. Chem. 2017, 73, 83-99. [CrossRef]

11. Abdalla, M.M.; Al-Omar, M.A.; Bhat, M.A.; Amr, A.E.; Al-Mohizea, A.M. Steroidal pyrazolines evaluated as aromatase and quinone reductase-2-inhibitors for chemoprevention of cancer. Int. J. Biol. Macromol. 2012, 50, 1127-1132. [CrossRef] [PubMed]

12. Abdelhalim, M.M.; El-Saidi, M.M.T.; Rabie, S.T.; Elmegeed, G.A. Synthesis of novel steroidal heterocyclic derivatives as antibacterial agents. Steroids 2007, 72, 459-465. [CrossRef] [PubMed]

13. Arenas-González, A.; Mendez-Delgado, L.A.; Merino-Montiel, P.; Padrón, J.M.; Montiel-Smith, S.; Vega-Báez, J.L.; Meza-Reyes, S. Synthesis of monomeric and dimeric steroids containing [1,2,4]triazolo[1,5-a]pyrimidines. Steroids 2016, 116, 13-19. [CrossRef] [PubMed]

14. Romero-Hernández, L.L.; Merino-Montiel, P.; Meza-Reyes, S.; Vega-Baez, J.L.; López, Ó.; Padrón, J.M.; Montiel-Smith, S. Synthesis of unprecedented steroidal spiro heterocycles as potential antiproliferative drugs. Eur. J. Med. Chem. 2018, 143, 21-32. [CrossRef] [PubMed]

15. Romero-López, A.; Montiel-Smith, S.; Meza-Reyes, S.; Merino-Montiel, P.; Vega-Baez, J.L. Synthesis of steroidal derivatives containing substituted, fused and spiro pyrazolines. Steroids 2014, 87, 86-92.

16. Viñas-Bravo, O.; Martínez-Pascual, R.; Vega-Báez, J.L.; Gómez-Calvario, V.; Sandoval-Ramírez, J.; Montiel Smith, S.; Meza-Reyes, S.; López-De la Rosa, A.; Martínez-Montiel, M.; Reyes, M.; et al. Rapid conversion of spirostans into furostan skeletons at room temperatura. Steroids 2012, 77, 59-66. [CrossRef] [PubMed]

17. Monks, A.; Scudiero, D.; Skehan, P.; Shoemaker, R.; Paull, K.; Vistica, D.; Hose, C.; Langley, J.; Cronise, P.; Vaigro-Wolff, A.; et al. Feasibility of a High-Flux Anticancer Drug Screen Using a Diverse Panel of Cultured Human Tumor Cell Lines. J. Natl. Cancer Inst. 1991, 83, 757-766. [CrossRef]

18. Chang, C.; Bahadduri, P.M.; Polli, J.E.; Swaan, P.W.; Ekins, S. Rapid Identification of P-glycoprotein Substrates and Inhibitors. Drug Metab. Dispos. 2006, 34, 1976-1984. [CrossRef]

19. Bergman, A.M.; Pinedo, H.M.; Talianidis, I.; Veerman, G.; Loves, W.J.; Van der Wilt, C.L.; Peters, G.J. Increased sensitivity to gemcitabine of P-glycoprotein and multidrug resistance-associated protein-overexpressing human cancer cell lines. Br. J. Cancer 2003, 88, 1963-1970. [CrossRef]

20. Castaing, M.; Loiseau, A.; Cornish-Bowden, A. Synergy between verapamil and other multidrug-resistance modulators in model membranes. J. Biosci. 2007, 32, 737-746. [CrossRef]

21. Miranda, P.O.; Padrón, J.M.; Padrón, J.I.; Villar, J.; Martín, V.S. Prins-type synthesis and SAR study of cytotoxic alkyl chloro dihydropyrans. ChemMedChem 2006, 1, 323-329. [CrossRef] [PubMed]

Sample Availability: Samples of the compounds are not available from the authors.

(C) 2019 by the authors. Licensee MDPI, Basel, Switzerland. This article is an open access article distributed under the terms and conditions of the Creative Commons Attribution (CC BY) license (http://creativecommons.org/licenses/by/4.0/). 